\title{
Improved Functionality of Foamed WPI Solutions by Ultrasound Application
}

\author{
Karina Martínez ${ }^{1 *}$ and Cecilio Carrera Sanchez ${ }^{2}$ \\ ${ }^{1}$ Departamento de Industrias, Facultad de Ciencias Exactas y Naturales, Universidad de Buenos Aires, Ciudad Universitaria (1428) Buenos Aires, Argentina \\ ${ }^{2}$ Departamento de Ingeniería Quimica, Facultad de Quimica, Universidad de Sevilla, C/Prof. García González, 1,41012 Seville, Spain
}

Correspondence to:

Karina Martínez

Departamento de Industrias

Facultad de Ciencias Exactas y Naturales

Universidad de Buenos Aires

Ciudad Universitaria (1428) Buenos Aires

Argentina

Tel: 541145763377

Fax: 541145763366

E-mail: karinamartinez@di.fcen.uba.ar

Received: February 24, 2016

Accepted: April 25, 2016

Published: April 26, 2016

Citation: Martínez K, Sanchez CC. 2016. Improved Functionality of Foamed WPI Solutions by Ultrasound Application. J Food Chem Nanotechnol 2(2): 79-84.

Copyright: () 2016 Martínez and Sanchez. This is an Open Access article distributed under the terms of the Creative Commons Attribution 4.0 International License (CC-BY) (http:// creativecommons.org/licenses/by/4.0/) which permits commercial use, including reproduction, adaptation, and distribution of the article provided the original author and source are credited.

Published by United Scientific Group

\begin{abstract}
The objective of this work was to determine the effect of ultrasound on the stability of foams of whey protein isolate. It was used an ultrasonic processor Vibra Cell Sonics, model VCX at a frequency of $20 \mathrm{kHz}$ and an amplitude of $20 \%$. For this study, two $\mathrm{pHs}$ and two concentrations of whey proteins were made to analyze the foaming properties by conductometric and optical methods. Measurements of the variations of surface pressure $(\pi)$ with the molecular area (A) of films were also analyzed at the air-water interface with an automated KSV Langmuir type. The foam stability parameters of whey proteins were worse when ultrasound were applied at $\mathrm{pH} 7$, whereas were improved or unchanged at $\mathrm{pH} 3$. In other hand, bubbles images analysis showed also concentration effect through evident viscosity increase at the high concentration used.
\end{abstract}

\section{Keywords}

Whey proteins, Ultrasound, Foaming properties, Interfacial properties

\section{Introduction}

Whey protein isolate, recognized as a valuable ingredient for food applications, can be used, at same time with a specific function, such as foam promoting and/or stabilizing agent. It is well known that they are a significant source of functional protein ingredients for many traditional and novel food products [1]. The main proteins in whey are $\beta$-lactoglobulin $(\beta-\lg ), \alpha$-lactalbumin $(\alpha-\operatorname{lac})$ and bovine serum albumin (BSA) and they account for $70 \%$ of total whey proteins [2]. These proteins are responsible for the functional properties of whey proteins, such as solubility in water, viscosity, gelation, emulsification, foaming, color, flavor and texture enhancement and offer numerous nutritional advantages to formulated products [3].

Due to the increasing consumer demand for high quality food, new safe and effective methods of food processing and preservation are being developed. Sound waves are generally considered safe, non-toxic, and environmentally friendly this gives the use of ultrasound a major advantage over other techniques [4]. Ultrasound can be applied to impart a specific molecular alteration through energy provided. For the food industry, this new technology could be of significant interest, as it allows "green" chemistry to be conducted, i.e. conducting chemical reactions using environmentally benign solvents and reactants [5].

The effect of high ultrasound intensity on proteins is related to cavitation, heating, dynamic agitation, shear stresses, and turbulence [6]. It may cause physical changes on proteins producing aggregates through non-covalent bonds 
by cyclic generation and collapse of cavities depending of structural and protein state aggregation [7].

In the present work, 2 and $6 \% \mathrm{wt} / \mathrm{wt}$ of whey protein isolate was prepared at $\mathrm{pH} 7$ and $\mathrm{pH} 3$, (concentrations and $\mathrm{pHs}$ used in food industrial preparations). Ultrasound was applied on solutions proteins in order to analyze the foaming stability effect, relating with interfacial properties at equilibrium conditions and the bubble size change during the destabilization process.

\section{Material and Methods}

Whey protein isolate solutions preparation and Zeta potential measurement

Whey protein isolate (WPI) was provided by Milkaut, Argentina. Two different concentrations were made in distilled water: 2 and $6 \% \mathrm{wt} / \mathrm{wt}$ and adjusted further to $\mathrm{pH} 7$ with $1 \mathrm{~N} \mathrm{NaOH}$ or $\mathrm{pH} 3$ with $1 \mathrm{M} \mathrm{HCl}$ respectively. After, they were maintained at cool temperature overnight. These final solutions using $10 \mathrm{ml}$ each time were treated by high intensity ultrasound (HIUS).

Zeta potential was measured for each $\mathrm{pH}$ solution of WPI samples by dynamic light scattering (Zetasizer Nano, Malvern Instruments, Malvern, U.K.), using $1 \mathrm{ml}$ of the solution samples.

\section{High-intensity ultrasound (HIUS) treatment}

Solutions of WPI were sonicated for $20 \mathrm{~min}$ using an ultrasonic processor Vibra Cell Sonics, model VCX 750 (maximum net power output: $750 \mathrm{~W}$ ) at a frequency of $20 \mathrm{kHz}$.

Time of sonication was selected conforming previous studies at different times [7] and was chosen the time where more pronounced was the HIUS effect on foaming properties.

The determined dissipated acoustic power in the liquid was $4.27 \pm 0.71 \mathrm{~W}$ [8] and an amplitude of $20 \%$ without any booster. A $13 \mathrm{~mm}$ high grade titanium alloy probe threaded to a $3 \mathrm{~mm}$ tapered microtip was used to treat $10 \mathrm{ml}$ of each solution. Samples contained into glass test tubes were, in turn, immersed into a glycerine-jacketed circulating constant temperature cooling bath at $0.5{ }^{\circ} \mathrm{C}$ to dissipate most of the heat produced during sonication.

\section{Solubility}

Previously, samples of WPI were prepared at different pHs and concentrations, 2, 4, 6 and 10\% wt/wt; ultrasound treated and compared with equal untreated concentration protein. As solubility after treatment resulted independent of concentration and $\mathrm{pH}$ used, the procedure of [9], was used. Samples prepared at $10 \% \mathrm{w} / \mathrm{w}$ were first HIUS-treated and then diluted at $2 \% \mathrm{w} / \mathrm{w}$. Control solutions were directly prepared at $2 \% \mathrm{w} / \mathrm{w}$. Protein dispersions were centrifuged at $12,857 \mathrm{x}$ g for $30 \mathrm{~min}$ at room temperature. The supernatant containing the total soluble fraction was lyophilized for $48 \mathrm{~h}$ in a Stokes freeze-dryer (Barber-Colman, Philadelphia PA 19120 , USA), operating at a condenser plate temperature of $40{ }^{\circ} \mathrm{C}$ and a chamber pressure of less than $100 \mathrm{~mm} \mathrm{Hg}$. Then, samples were weighted and solubility was expressed as:
$\mathrm{S} \%=$ total soluble solids $(\mathrm{g}) /$ total solids $(\mathrm{g}) \times 100$

Foam formation and stability

The foaming properties of protein solutions were characterized through their foam stability, measured in a commercial instrument, (Foamscan IT Concept, Longessaigne, France) as described elsewhere [10].

To characterize the obtained foam, the relative foam conductance was analyzed (Cf\%) where is a measure of foam density and was determined by Eq. (2).

$$
C f=C \text { foam }(f) / C \operatorname{lig}(f) \times 100
$$

Where $C$ foam $(f)$ and $C \operatorname{liq}(f)$ are the final foam and liquid conductivity values, respectively.

The foam stability was determined from the volume of liquid drained from the foam over time $[11,12]$.

The half-life time to drain ( $t$ drain $1 / 2$ ), referring to the time needed to drain V/2 can be expressed by Eq. (3) corresponding to an empirical second-order equation.

$t$ drain $1 / 2=\left(\mathrm{k}_{2} \mathrm{~V}_{\mathrm{o}}\right)^{-1}$

Where $\mathrm{V}_{0}$ is the liquid volume $(\mathrm{ml})$ in the foam at time $\mathrm{t}=$ 0 and $\mathrm{k}_{2}$ is the second order drainage rate constant $\left(\mathrm{min} / \mathrm{ml}^{-1}\right)$.

The foam stability was also determined by the time evolution of the foam conductivity [13] through the follows equation (Eq. (4)):

$$
C t / C_{0}=A 1 \exp (-t / t d)+A 2 \exp (-t / t d c)
$$

which indicates that more than one mechanism is operative in the foam breaking, where A1 and A2 are adjustable parameters and $t d$ and $t d c$ are the relaxation times, which can be related to the kinetics of liquid drainage from the foam (including the gravitational drainage and marginal regeneration) and disproportionation and foam collapse, respectively [13].

The evolution of the bubble size change in the foam was also determined by a second CCD camera set as described elsewhere [10].

\section{Surface film balance}

Measurements of the variations of surface pressure $(\pi)$ with the molecular area (A) of WPI were done at the air-water interface with an automated KSV Langmuir mini-trough (KSV Instruments Ltd., Helsinki, Finland). The surface pressure was measured with a Wilhelmy plate and an accuracy of $\pm 0.1 \mathrm{mN} / \mathrm{m}$. The sub phase in the trough was Milli-Q water at corresponding $\mathrm{pH}$ of each measure and all the measurements were performed at constant temperature $(20 \pm$ $1{ }^{\circ} \mathrm{C}$ ) by a thermostat [14]. As the spreading of proteins is a critical step in the study, it was used the Trurnit's spreading method [15] and the technique for soluble proteins [14].

\section{Statistical analysis}

All the experiments were performed in duplicate or triplicate. The model goodness-of-fit was evaluated by the coefficient of determination $\left(R^{2}\right)$ and the analysis of variance by homogeneous groups (ANOVA) which indicates a significant difference at $\mathrm{P}<0.05$, using Statgraphics Plus 3.0. Software. 


\section{Results and Discussion}

\section{Zeta potential measurement}

The results showed for $2 \% \mathrm{w} / \mathrm{w}$ at $\mathrm{pH} 7$ and $\mathrm{pH} 3$ WPI solutions a $\zeta$ potential of $-18.4 \pm 1$ and $21.2 \pm 1.2 \mathrm{mV}$ respectively; and $6 \% \mathrm{w} / \mathrm{w}$ at $\mathrm{pH} 7$ and $\mathrm{pH} 3 \mathrm{WPI}$ solutions a $\zeta$ potential of $-25.5 \pm 1.2$ and $28.2 \pm 1.2 \mathrm{mV}$ respectively. Similar values were obtained by Chutima et al. and Jambrak et al. $[16,17]$.

\section{Effects of HIUS on stability parameters of foams}

The characterization and stability of foams were studied by the relative foam conductivity ( $C f \%$ ), the time of half drainage (t. drain $1 / 2$ ), the relaxation time corresponding to the kinetics of liquid drainage from the foam $(t d)$ and the relaxation time corresponding to the kinetics of disproportionation and foam collapse $(t d c)$.

Table 1 shows $t$. drain $1 / 2$ and $C f \%$ for 2 and $6 \% \mathrm{wt} / \mathrm{wt}$ of WPI, at $\mathrm{pH} 7$ and $\mathrm{pH} 3$ respectively. It was clearly observed a decrease of parameters at $\mathrm{pH} 7$ at each concentration when HIUS was applied (Table 1A). However, the results were practically opposed at $\mathrm{pH} 3$ in the same conditions. Apparently, the protein charge, is the main factor that governs the ultrasound effects on these parameters, due to principal difference between these proteins solutions, leading also to alter the molecular interfacial structure in different way. The results showed beneficial effects for the foams stability when HIUS were applied on WPI solutions at $\mathrm{pH} 3$. In these conditions, it was observed that $t$. drain $1 / 2$ increased (improvement of foam stability) at $2 \% \mathrm{wt} / \mathrm{wt}$ or keeps unaffected at $6 \% \mathrm{wt} / \mathrm{wt}$, conforming significance analysis, maybe due to viscosity effects (Table 1B). The increment of bulk viscosity due to concentration, may retard all destabilization mechanisms; tending to delay the phase separation of the dispersed system [18] leading in this case to higher time needed to drain same liquid quantity.

In other hand, $C f \%$ increased more than three times at $2 \% \mathrm{wt} / \mathrm{wt}$ after HIUS treatment at $\mathrm{pH} 3$, indicating a positive

Table 1: Drainage half time and relative conductivity, for 2 and $6 \mathrm{wt} / \mathrm{wt}$ at (A) $\mathrm{pH} 7$; and (B) $\mathrm{pH} 3$.

Different letters for the same sample with HIUS effect for each parameter indicates a significant difference at $\mathrm{P}<0.05$.

A.

\begin{tabular}{|c|c|c|}
\hline & t.dren $\mathbf{1 / 2}$ & $C_{f}(\%)$ \\
\hline $\mathbf{2 \%}$ & $271 \pm 2^{\mathrm{a}}$ & $10.6 \pm 1.27^{\mathrm{a}}$ \\
\hline $\mathbf{2 \%}$ HIUS & $154.5 \pm 29^{\mathrm{b}}$ & $1.88 \pm 0.93^{\mathrm{b}}$ \\
\hline $\mathbf{6 \%}$ & $601 \pm 6^{\mathrm{a}}$ & $31.1 \pm 2.34^{\mathrm{a}}$ \\
\hline $\mathbf{6 \%}$ HIUS & $255.5 \pm 57^{\mathrm{b}}$ & $9.75 \pm 2.71^{\mathrm{b}}$ \\
\hline
\end{tabular}

B.

\begin{tabular}{|c|c|c|}
\hline & t.dren $\mathbf{1 / 2}$ & $\boldsymbol{C f}(\%)$ \\
\hline $\mathbf{2 \%}$ & $73 \pm 0^{\mathbf{a}}$ & $5.68 \pm 0.96^{\mathrm{a}}$ \\
\hline $\mathbf{2 \%}$ HIUS & $162 \pm 8^{\mathrm{b}}$ & $18.27 \pm 3.4^{\mathrm{b}}$ \\
\hline $\mathbf{6 \%}$ & $154.5 \pm 17^{\mathrm{a}}$ & $16.4 \pm 1.37^{\mathrm{a}}$ \\
\hline $\mathbf{6 \%}$ HIUS & $180.5 \pm 47^{\mathrm{a}}$ & $13.13 \pm 1.19^{\mathrm{a}}$ \\
\hline
\end{tabular}

increment of protein incorporated in the foam.

The Table 2 shows relaxation times corresponding to the kinetics of foam destabilization; $t d$ and $t d c$ at $\mathrm{pH} 7$ and $\mathrm{pH} 3$ at 2 and $6 \% \mathrm{w} / \mathrm{w}$ of WPI.

Firstly, it is worth to denote that the increment of these parameters after treatment would indicate an improvement for foam destabilization [19].

In the Table 2, can be seen a decrease of $t d$ as a consequence of HIUS treatment for WPI at every concentration at $\mathrm{pH}$ 7 and $6 \% \mathrm{w} / \mathrm{w}$ of protein at $\mathrm{pH} 3$, indicating an increase of destabilization parameters coming from kinetics of liquid drainage. Thus, these results could be indicated a favorable HIUS effects just for $2 \% \mathrm{w} / \mathrm{w}$ of protein at $\mathrm{pH} 3$ in this

Table 2: Relaxation times corresponding to the kinetics of foam destabilization; $t d$ and $t d c$ at $\mathrm{pH} 7$ and 3 at 2 and $6 \%$ w/w of WPI.

Different letters for the same sample with HIUS effect for each parameter indicates a significant difference at $\mathrm{P}<0.05$.

\begin{tabular}{|c|c|c|}
\hline $\boldsymbol{p H 7}$ & $\boldsymbol{t} \boldsymbol{t}$ & $\boldsymbol{t} \boldsymbol{c}$ \\
\hline $\mathbf{2 \%}$ & $128 \pm 5.33^{\mathbf{a}}$ & $912 \pm 16.55^{\mathbf{a}}$ \\
\hline $\mathbf{2 \%}$ HIUS & $115 \pm 0.7^{\mathbf{b}}$ & $1100 \pm 48.1^{\mathbf{b}}$ \\
\hline $\mathbf{6 \%}$ & $228 \pm 1.4^{\mathbf{a}}$ & $2739 \pm 38.4^{\mathbf{a}}$ \\
\hline $\mathbf{6 \% ~ H I U S}$ & $150 \pm 1.9^{\mathbf{b}}$ & $1453 \pm 25.6^{\mathbf{b}}$ \\
\hline $\boldsymbol{p H 3}$ & & \\
\hline $\mathbf{2 \%}$ & $66.7 \pm 4.5^{\mathbf{a}}$ & $501 \pm 42.5^{\mathbf{a}}$ \\
\hline $\mathbf{2 \%}$ HIUS & $138 \pm 3.2^{\mathbf{b}}$ & $857 \pm 66.3^{\mathbf{b}}$ \\
\hline $\mathbf{6 \%}$ & $123 \pm 1.4^{\mathbf{a}}$ & $1631 \pm 49.3^{\mathbf{a}}$ \\
\hline
\end{tabular}

conditions.

However, for $t d c$ an increase of stability corresponding to disproportion and collapse from kinetics parameters were observed for both concentrations at $\mathrm{pH} 3$ and 2\% w/w of protein at $\mathrm{pH} 7$. These results show the complexity of variables leading to increase or decrease the overall foam stability. Some authors [20] have been demonstrated that the foam stability increased with protein concentration in solution as can be seen in the current work. These results were also in agreement with the interfacial characteristics of the adsorbed films. At the higher protein concentrations in solution the foam stability was practically the same no matter what the protein were analyzed, in agreement with the interfacial characteristics of the adsorbed. These reference data confirm that for a particular protein the overall foam destabilization ( $t$. drain $1 / 2)$ and the individual destabilization processes (drainage, disproportionation and coalescence) may be related to the interfacial characteristics (protein concentration at the interface, structure, topography, and interfacial shear and dilatational characteristics) of the protein film adsorbed around the bubbles [10].

In addition, ultrasound is able to produce effects through physical, mechanical and chemical changes by the acoustic cavitation which can accelerate chemical reactions, increase diffusion rates, disperse aggregates, break down small particles and polymeric materials such as enzymes and destroy microorganisms [19]. Due to flexibility; hydrophobic/ 
hydrophilic balance, charge modification of peptides after treatment, functional properties of proteins in foods are modified such as solubility, foaming capacity and stability between others properties $[8,21]$.

\section{Effect of HIUS on bubbles images of foams}

Figures 1 and 2 shows the images of air bubbles throughout aging of WPI foams: (a) control and (b) HIUS treated solutions at $\mathrm{pH} 7$ and $\mathrm{pH} 3$ respectively, at 2 and $6 \% \mathrm{wt} / \mathrm{wt}$.

The images correspond to destabilization of foams, thus, they show the images from the end of bubbling process.

As the images were taken in a fixed time of $3.6 \mathrm{~min}$, the number of images for every system was different depending on the stability throughout the total foam collapse. Therefore, as much images obtained, higher stability was found.

In many systems, when HIUS were applied, more liquid quantity is incorporated, promoting more stable foam with small and monomodal size bubble distribution, however, in the current work, less tendency of liquid incorporation was found due to molecular structure change after treatment. Some authors found similar tendency $[8,13,17,20]$. It can be observed that HIUS effect on 2\% WPI solution, depend on

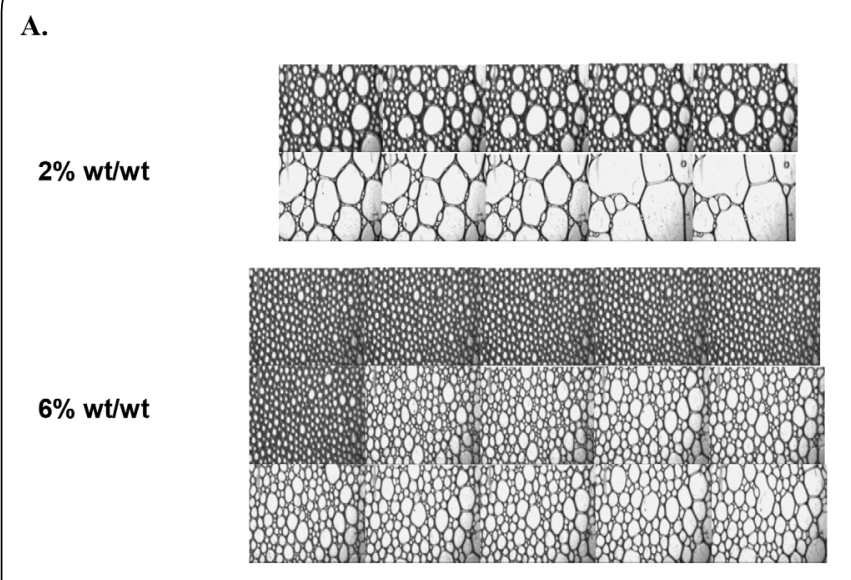

B.

$2 \% \mathrm{wt} / \mathrm{wt}$

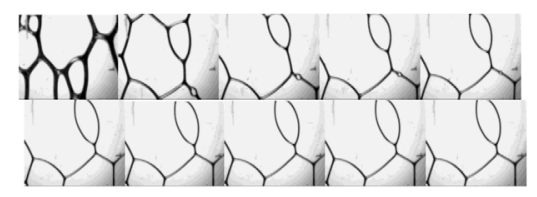

$6 \% \mathrm{wt} / \mathrm{wt}$

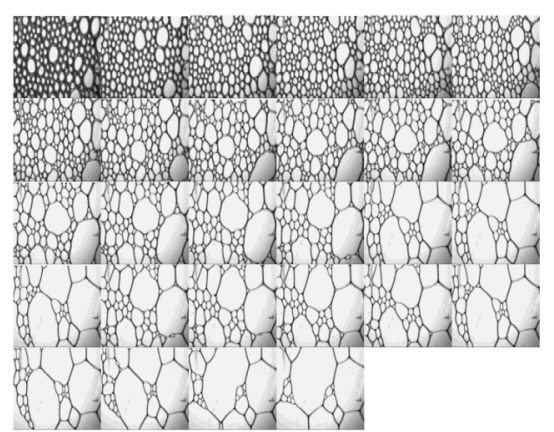

Figure 1: Light micrographs showing the development with time of air bubbles at the end of bubbling process for WPI at 2 and $6 \% \mathrm{w} / \mathrm{w}$ at $\mathrm{pH} 7,(\mathrm{~A})$ without HIUS (B) HIUS treated.
$\mathrm{pH}$. At $\mathrm{pH} 7$ it produced a very less liquid incorporation in the foam (Table 1A), which can be seen by the size of bubbles in the Figure 1. The bigger size and lower bubbles quantity denoted a dryer foam formation (Figure 1) with similar stability against collapse. Same tendency was found at $6 \% \mathrm{wt} / \mathrm{wt}$, where clearly dryer foam was obtained after HIUS treatment, with heterogeneous appearance and bigger bubbles by comparing with untreated $6 \% \mathrm{wt} / \mathrm{wt}$ WPI solution at this $\mathrm{pH}$. However, more number of images was taken denoting more stability index against collapse of foam at high protein concentration, attributed to viscosity increase effects. The observed decrease of solution incorporation to the foam after HIUS treatment, can be related as same way with the $C f \%$ decrease, observed at both concentrations (Table 1A).

The Figure 2 shows HIUS effect for 2 and 6\% wt/wt at $\mathrm{pH}$ 3. At this $\mathrm{pH}$, can be seen that HIUS was not the responsible for liquid incorporation decrease ( $C f \%$ decrease, Table $1 \mathrm{~B})$. In this case, the $C f \%$ increment for $2 \% \mathrm{w} / \mathrm{w}$ of protein after HIUS treatment conduce to lower bubble size with a notable polimodal size distribution and evident stability increase against collapse as images bubbles shown. In other hand, when $6 \% \mathrm{w} / \mathrm{w}$ of protein was studied, in spite of $C f \%$ decrease (Table 1B), higher number of images were obtained indicating more stability of system against collapse.

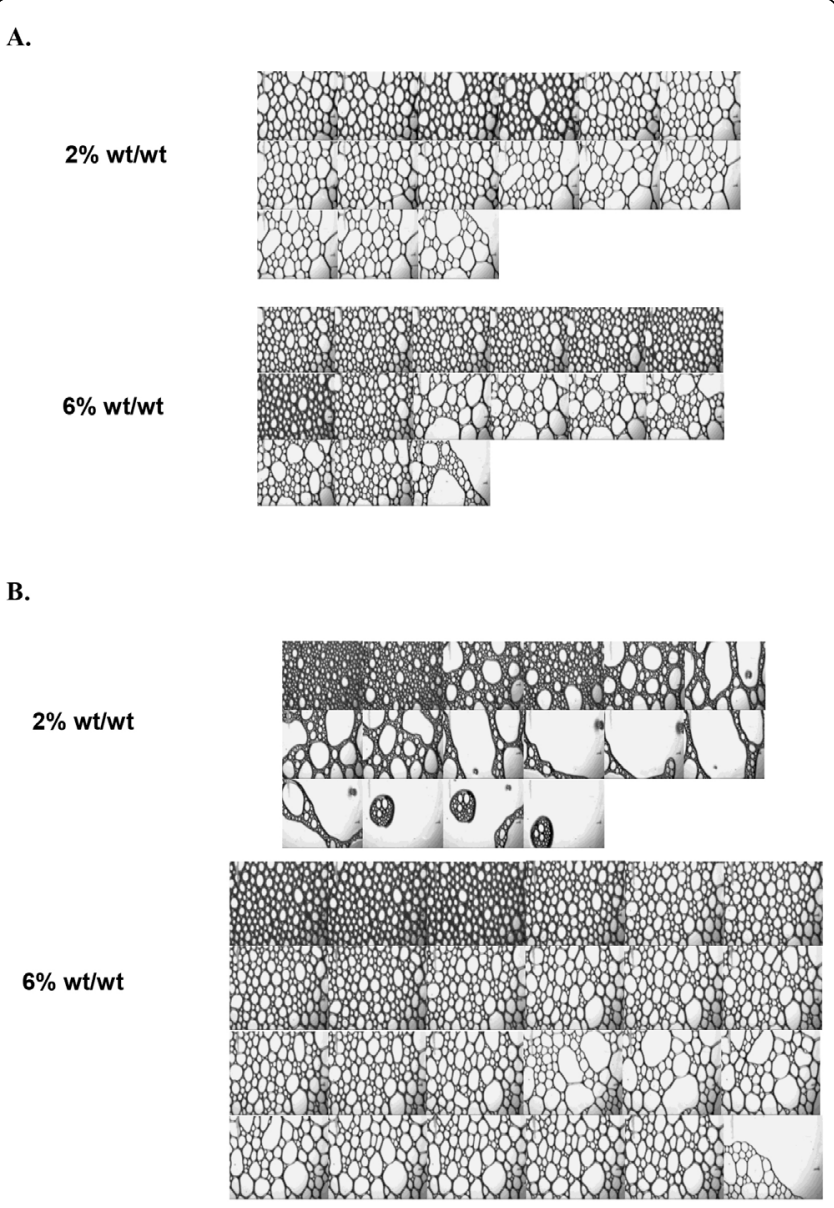

Figure 2: Light micrographs showing the development with time of air bubbles at the end of bubbling process for WPI at 2 and $6 \% \mathrm{w} / \mathrm{w}$ at $\mathrm{pH} 3,(\mathrm{~A})$ without HIUS (B) HIUS treated. 


\section{Surface film balance}

Structural characteristics of spread monolayers at the airwater interface

The structural characteristics of WPI spread monolayers depend on film ageing. The ageing effect is due to unfolding of the protein at the interface, which can be related with stability parameters of foams. A change in the monolayer structure trough expansion or compression of their isotherms, would indicate more or less space occupied by spread protein.

The Figure 3 shows the variations of surface pressure $(\pi)$ with the molecular area (A) at the air-water interface for WPI and HIUS treated samples at $\mathrm{pH} 7$ and $\mathrm{pH} 3$ respectively.

It can be observed the isotherm from HIUS treated WPI solution displaced on the $\pi$-A axis depending on the $\mathrm{pH}$. There existed a shift of the $\pi$-A isotherm to lower values of area when HIUS were applied at $\mathrm{pH}$ 7. The displacement at left may be related with condensation of the peptides from WPI after treatment [8].

However, when HIUS were applied at $\mathrm{pH} 3$ solution the resulting isotherm presented a similar behavior than the obtained from the untreated protein at same $\mathrm{pH}$. Clearly, the $\mathrm{pH}$ has a complex effect on the spreading of whey protein isolate at equilibrium.

A.

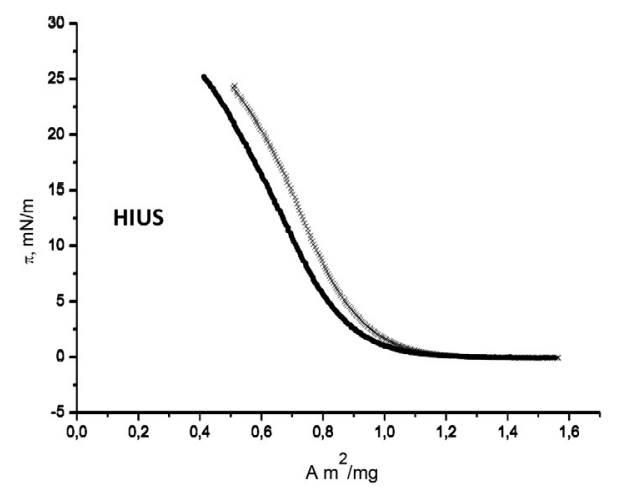

B.

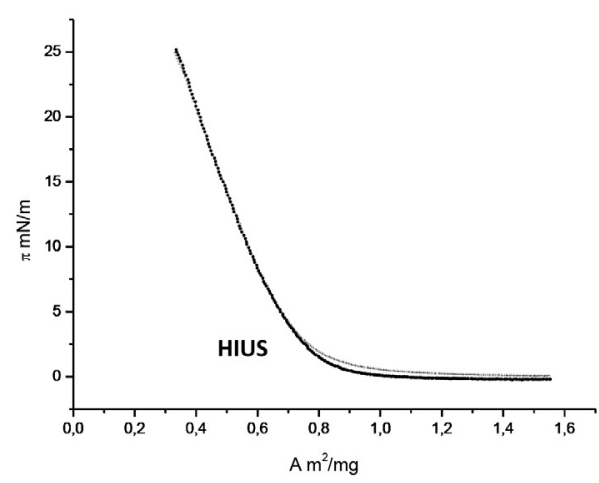

Figure 3: Surface pressure isotherms $(\pi)$ vs Area for WPI and HIUS treated WPI at $(\mathbf{A})$ at $\mathrm{pH} 7$ (B) at $\mathrm{pH} 3$.

\section{Conclusions}

Solubility decreased from 67 to $62 \% \pm 0.7$ for all solutions after HIUS application in the current work. Although the ultrasound produced a decrease of solubility at both $\mathrm{pHs}$, however, just at $\mathrm{pH} 7$ this technique apparently had an effect on aggregation or condensation state of whey protein isolate at both concentrations used, 2 and $6 \% \mathrm{w} / \mathrm{w}$, which determined a detrimental effect of their stability parameters (liquid incorporation, liquid drainage $1 / 2 ; t d$ and $t d c$ relaxation times) and macroscopic ones (bubbles size and distribution) at this $\mathrm{pH}$.

Nevertheless, when HIUS was applied on solutions proteins at $\mathrm{pH} 3$, even solubility decrease occurs, monolayer structure of proteins at liquid interface would not aggregate, promoting a better interfacial conformation which lead to the increment of stability parameters of foams and higher protein solution incorporation to the foam formed.

In other hand, from the point of view of the bubble images study, the results showed evident viscosity effects due to WPI higher concentration at both $\mathrm{pH}$ studied.

\section{Acknowledgments}

Research supported byConsejo NacionaldeInvestigaciones Científicas y Técnicas de la República Argentina (CONICET), UBA (UBACYT 20020100200221), ANPCyT (PICT 20081901) and Departamento de Ingeniería Química, Facultad de Química, Universidad de Sevilla, Spain.

\section{Conflict of Interest}

The authors declare no conflict of interest.

\section{References}

1. Mishra S, Mann B, Joshi VK. 2001. Functional improvement of whey protein concentrate on interaction with pectin. Food Hydrocoll 15(1): 9-15. doi: 10.1016/S0268-005X(00)00043-6

2. Cayot P, Lorient D. 1997. Structure-function relationships of whey proteins. In: Damodaran S, Paraf A (eds) Food Proteins and Their Applications. Marcel Dekker Inc., New York, USA, pp 225-256.

3. Krešic G, Lelas V, Jambrak AR, Herceg Z, Brnc `ic SR. 2008. Influence of novel food processing technologies on the rheological and thermo physical properties of whey proteins. J Food Eng 87(1): 64-73. doi: 10.1016/j.jfoodeng.2007.10.024

4. Kentish S, Ashokkumar M. 2011. The physical and chemical effects of ultrasound. In: Feng H, Barbosa-Cánovas GV, Weiss J (eds) Ultrasound Technologies for Food and Bioprocessing. Springer New York, USA, pp 1-12. doi: 10.1007/978-1-4419-7472-3_1

5. Weiss J, Kristbergsson K, Kjartansson GT. 2011. Engineering food ingredients with high-intensity ultrasound. In: Feng $\mathrm{H}$, BarbosaCánovas GV, Weiss J (eds) Ultrasound Technologies for Food and Bioprocessing. Springer New York, USA, pp 239-285. doi: 10.1007/9781-4419-7472-3_10

6. Knorr D, Zenker M, Heinz V, Lee D. 2004. Applications and potential of ultrasonics in food processing. Trends in Food Science E Technology 15(5): 261-266. doi: 10.1016/j.tifs.2003.12.001

7. Morales R, Martínez KD, Ruiz-Henestrosa VMP, Pilosof AM. 2015. Modification of foaming properties of soy protein isolate by high ultrasound intensity: Particle size effect. Ultrason Sonochem 26: 48-55. doi: 10.1016/j.ultsonch.2015.01.011

8. Arzeni C, Martínez K, Zema P, Arias A, Perez OE, et al. 2012. 
Comparative study of high intensity ultrasound effects on food proteins functionality. J Food Eng 108(3): 463-472. doi: 10.1016/j. jfoodeng.2011.08.018

9. Martinez KD, Sanchez CC, Patino JMR, Pilosof AMR. 2009. Interfacial and foaming properties of soy protein and their hydrolysates. Food Hydrocoll 23(8): 2149-2157. doi: 10.1016/j.foodhyd.2009.03.015

10. Sanchez CC, Patino JMR. 2005. Interfacial, foaming and emulsifying characteristics of sodium caseinate as influenced by protein concentration in solution. Food Hydrocoll 19(3): 407-416. doi: 10.1016/j. foodhyd.2004.10.007

11. Patino JMR, Naranjo MD, Linares JA. 1995. Stability and mechanical strength of aqueous foams containing food proteins. Colloids and Surfaces A-Physicochemical and Engineering Aspects 99(1): 65-78. doi: 10.1016/0927-7757(95)03129-2

12. Patino JMR, Niño MRR, Alvarez JM. 1997. Interfacial and foaming characteristics of protein-lipid systems. Food Hydrocoll 11(1): 49-58. doi: 10.1016/S0268-005X(97)80010-0

13. Martínez K, Sanchez CC. 2014. Ultrasound as a method to control protein-polysaccharide foam stability by microscopic parameter alteration. Journal of Food Processing and Preservation 39(6): 1272-1277. doi: $10.1111 /$ jfpp. 12345

14. Sánchez CC, Niño MRR, Ortiz SEM, Añon MC, Patino JMR. 2004. Soy globulin spread films at the air-water interface. Food Hydrocoll 18(2): 335-347. doi: 10.1016/S0268-005X(03)00089-4
15. Trurnit HJ. 1960. A theory and method for the spreading of protein monolayers. J Colloid Sci 15(1): 1-13. doi: 10.1016/0095-8522(60)90002-7

16. Thongkaew C, Hinrichs J, Gibis M, Weiss J. 2015. Sequential modulation of $\mathrm{pH}$ and ionic strength in phase separated whey protein isolate-Pectin dispersions: Effect on structural organization. Food Hydrocoll 47: 21-31. doi: 10.1016/j.foodhyd.2014.11.006

17. Jambrak AR, Mason TJ, Lelas V, Krešić G. 2010. Ultrasonic effect on physicochemical and functional properties of $\alpha$-lactalbumin. $L W T$-Food science and Technology 43(2): 254-262. doi: 10.1016/j.lwt.2009.09.001

18. Dickinson E. 2003. Hydrocolloids at interfaces and the influence on the properties of dispersed systems. Food Hydrocoll 17(1): 25-40. doi: 10.1016/S0268-005X(01)00120-5

19. Jambrak AR, Mason TJ, Lelas V, Herceg Z, Herceg IL. 2008. Effect of ultrasound treatment on solubility and foaming properties of whey protein suspensions. J Food Eng 86(2): 281-287. doi: 10.1016/j. jfoodeng.2007.10.004

20. Patino JMR, Conde JM, Linares HM, Sánchez CC, Pizones V, et al. 2007. Interfacial and foaming properties of enzyme-induced hydrolysis of sunflower protein isolate. Food Hydrocoll 21(56): 782-793. doi: 10.1016/j.foodhyd.2006.09.002

21. Gekko K, Yamagami K. 1991. Flexibility of food proteins as revealed by compressibility. J Agric Food Chem 39(1): 57-62. doi: 10.1021/ jf00001a010 